\title{
Information practices of allergic children's mothers
}

\author{
Adriana Bogliolo Sirihal Duarte \\ Flávia Moraes Moreira Barros \\ Universidade Federal de Minas Gerais - UFMG, Brasil
}

ORIGINAL

\begin{abstract}
Objectives. It is questioned how the information practices of mothers of children with food allergies influence their daily life, with the general aim of analyzing these practices under the social paradigm of Information Science.

Method. The methodology adopted is the qualitative and the method is the application of semi-structured in-depth interviews. Seven mothers of children with food allergies were interviewed. The data were analyzed applying the twodimensional information practices model proposed by McKenzie and the extended version of it stated by Yeoman.

Results. From the interviews, information practices adopted by mothers were identified and coded. Each of the codes was related to the models adopted.

Conclusions. It was possible to observe the existence of all modes and phases present in the models. It was also possible to observe the relevance of the mothers' information practices to maintain the quality of life for their allergic children.biblioteca.
\end{abstract}

Keywords

Feeding safety; Food allergy; Information practices; Information science social paradigm; User studies

\section{Prácticas de información de las madres de niños alérgicos}

\section{Resumen}

Objetivos. Se cuestiona cómo las prácticas informativas de madres de niños con alergias alimentarias influyen en su vida cotidiana, con el objetivo general de analizar estas prácticas bajo el paradigma social de las Ciencias de la Información.

Método. La metodología adoptada es la cualitativa y el método es la aplicación de entrevistas semi-estructuradas en profundidad. Siete madres de niños con alergias alimentarias fueron entrevistadas. Los datos fueron analizados aplicando el modelo de prácticas de información bidimensional propuesto por McKenzie y la versión extendida del mismo establecida por Yeoman.

Resultados. De las entrevistas se identificaron y codificaron las prácticas informativas adoptadas por las madres. Cada uno de los códigos estaba relacionado con los modelos adoptados.

Conclusiones. Se pudo observar la existencia de todos los modos y fases presentes en los modelos. También se pudo observar la pertinencia de las prácticas informativas de las madres para mantener la calidad de vida de sus hijos alérgicos.

\section{Palabras clave}

Alergia alimentaria; Estudios de usuario; Paradigma social de las ciencias de la información; Prácticas de información; Seguridad alimentaria

\section{Introduction}

According to data released in 2009 by the Brazilian Association of Allergy and Immunology (Associação Brasileira de Alergia e Imunologia - ASBAI, 2009), food reactions of allergic causes affect approximately 6-8\% of children under 3 years old and $2-3 \%$ of adults. In some of these cases, according to the same Association, consumption of the allergy-causing substance can lead to health damage, ranging from skin reactions (hives, swelling) and problems in the gastrointestinal tract to more severe manifestations that can lead to cases of anaphylactic reaction. 
The anaphylactic reaction, according to ASBAI (2009), "is a sudden, severe reaction that imposes immediate care because it is potentially fatal. [...] In food allergy, food induces the massive release of chemicals that will determine a serious picture of systemic response [...]". Food allergies are a result of immaturity of the immune system, which, in most cases, usually, over time, come to tolerate substances that once did harm to the body.

The human organism has two differents ways of reacting, which are termed as mediated allergy and unmediated allergy. In mediated allergy, the person drinks a glass of milk, for example, and soon afterwards he already has vomiting, itching, diarrhea, among other symptoms. Children with this type of immediate reactions have the $E$ antibody greatly increased. In the medical field, it is then said that the allergy is "mediated" by antibody E. The other type of allergy is the one in which reactions take longer to occur (up to 72 hours after taking the allergen) and are generally intestinal symptoms. In these cases, other defense cells (not antibody E) are involved, which leads to the term "non-mediated" allergy. There are also individuals who present both types of allergy, being denominated as mixed.

Even when there is no risk of death, food allergy becomes an obstacle to a satisfactory quality of life, as well as can cause limitations to human development, especially in childhood. In this scenario, the parents of these children must have access to the information in order to be able to choose correctly what should be given to them and what types of food should not be consumed.

When it comes to health, every case is unique. Within the group of allergic individuals, a substance that causes only a slight itch in one person may be the cause of an anaphylactic shock in another. Therefore, there is no rules to be followed when a child is found to be allergic. It is up to parents and caregivers, therefore, to seek medical help in order to identify substances that should be avoided in food. And so, act in the identification of products and substances that can be consumed without causing allergic reactions.

This process, however, is not simple. Those responsible for an allergic child undertake a routine for information seeking and can never fail to get updates on changes in food labeling standards, check for changes in the ingredients of any product since last consumption, contact the Consumer Assistance Services (in Brazil called Serviço de Assistência ao Consumidor - SAC) of companies to know more about the composition of a food, among other practices.

The importance of this information seeking behavior is perceived in a survey conducted in 2009 by the Allergy and Immunology Unit of the Children's Institute of the Hospital of the Medical School of the University of São Paulo, which showed that $48.1 \%$ of the relatives of patients with milk allergy stated doubts when reading the labels, and, in case of doubts, $71.2 \%$ of the sample excluded the product of the child's diet (Binsfeld et al., 2009). This means that the difficulty in understanding and accessing information causes doubts and insecurities in these families, who already should cope with the difficulties of restrictive feeding. The study also concluded that $39.5 \%$ of the allergic reactions occurred among children already diagnosed with the problem were due to errors in the reading of labels. Thus, it is not necessarily perceived as negligence of the relatives on the subject, but rather a possible lack of information at the time of purchase.

Adequate information helps to solve problems and, in the specific case which is focus of this research, ensures the health and quality of life of children affected by food allergy. One measure that may facilitate the routine of these people is the labeling of allergens in Brazil, which discussion started in May 2014, and which enabled the adoption of a regulatory rule of the issue. In June of the same year, Public Consultation No. 29/2014 was carried out, which "deals with the obligation to declare, on the labeling of packaged foods, sources that are known to cause food allergies or intolerances in susceptible persons" (Agência Nacional de Vigilância Sanitária, 2014). On June 24, 2015, a law was approved, whereby manufacturers are required to report on the labels the presence of 17 foods (wheat, crustaceans, eggs, fish, peanuts, soybeans, milk from all mammals, almonds, hazelnuts, cashew nuts, Pará nuts, macadamia nuts, pecans, pistachios, pinoli, nuts, as well as natural latex). A period of 12 months has been granted for adaptation to the law. This fact represented a breakthrough, since the lack of this regulation made it even more difficult to choose the menu of allergic individuals. In June 2016, the regulation began to be valid, which was followed by several manufacturers. Companies that do not adopt the new labels can be penalized with warning, disablement, ban and / or fine (Brasil, Law No. 6.437, August 20, 1977). 
In general, therefore, the information practices adopted by the mothers of children with food allergies will be analyzed under the social paradigm of Information Science, aiming at the promotion of a better quality of life for their children and the guarantee of their feeding safety. Specifically, this work intends to achieve 3 specific goals, namely:

1. Discuss possible relationships between the information practices adopted by the mothers of children with food allergies and the maintenance of the quality of life and feeding safety of these children;

2. To know the processes information seeking made by the mothers of allergic children in order to offer them a correct feeding;

3. To portray the most common practices adopted by mothers of allergic children in the search, sharing, and dissemination of information appropriate to their children's conditions, based on the two-dimensional model of information practices proposed by McKenzie (2003) and the extended model stated by Yeoman (2010), both presented below.

Two aspects justify the conduct of this research: to favor the discussion on child food allergy in Brazil, especially in a moment of evidence of the matter in the country, due to the regulation of the labeling of allergens in 2015 , and to contribute to the studies of the social paradigm of Users Studies in Information Science. It is believed that through this research, it will be possible to obtain new insights and contribute to a better understanding of the process of information practices, to promote advances in studies related to the information needs presented by users. It is important to highlight that this research is probably the first Brazilian study to test the information practices model developed by McKenzie (2003) and its extended version proposed by Yeoman (2010). Although these models have already been discussed in Brazilian literature by Rocha, Sirihal Duarte, and Paula (2017), there is no empirical research associated with this discussion.

\section{The User Studies in the Social Paradigm of Information Science}

The main advance of the social paradigm in Information Science was the recognition that the individual is part of a social context, acting on suffering interferences of it. By this logic,

\footnotetext{
the subject is not seen as an isolated being, detached from social relations and from a broader sociocultural context, nor understood only as a cognoscenti being, who relates to the world only by filling "pieces" of knowledge with what he already has in the mind. In opposition to this (cognitive) form of understanding, information is considered as a social construction, something that is defined in the realm of the concrete action of subjects in reciprocal actions (i.e., interactions) ... (Araújo, 2012, p.146).
}

Human beings, in constant interaction, are recognized by the social paradigm as "producers of meaning, who are articulated in diverse communities of different natures: professional, ethnic, religious, sexual, political, economic, etc." (Araújo, 2008, p. 11)

Among the authors who include aspects of the social paradigm in their work, Birger Hjørland (2002) identifies problems in traditional user studies research. According to him, even with the great amount of work already done on the subject, adequate theories are lacking that can guide the research in this field. One of the causes of the lack of a consistent theoretical framework is the fact that previous research has: 
neglected culturally mediating factors in people's relationship with information and just tried to study generalized persons' relation to something termed "information". In these traditions people are expected to react to something in a specific, mechanical way without considering the culturally determined meanings and without considering the different goals and values of the meanings and of the documents. (Hjørland, 2002, p.431).

As an alternative to this perspective, Hjørland \& Albrechtsen (1995) propose the domain-analytic paradigm, an approach that can be understood from three aspects, according to the authors:

\begin{abstract}
The domain-analytic paradigm is thus firstly a social paradigm, conceiving of IS as one of the social sciences, promoting a social psychological, a sociolinguistic, a sociology of knowledge, and a sociology of science perspectives on IS. The domain-analytic paradigm is secondly a functionalist approach, attempting to understand the implicit and explicit functions of information and communication and to trace the mechanisms underlying informational behavior from this insight. Thirdly it is a philosophical-realistic approach, trying to find the basis for IS in factors that are external to the individualistic-subjective perceptions of the users as opposed to for example the behavioral and cognitive paradigms. (Hjørland \& Albrechtsen, 1995, p. 400).
\end{abstract}

Bernd Frohmann (2008) also endorses the studies of the social paradigm, by criticizing the mentalist concept, according to which information is perceived as something present in the mind of the individual from a text reading or by accessing it through other means, without considering the "social, public, economic and cultural aspects of information" (Frohmann, 2008).

Rendón Rojas (2005), in an analysis of three concepts relevant to Information Science (information, knowledge, and value), argues that the construction of knowledge occurs from the moment the person interprets the world and begins to interact with it. Thus, the relation between information and knowledge, and the process of value creation within the society are affected in the constructions carried out by the person, based on internal and external perceptions.

Even with these initiatives, however, Araújo (2010b) points out that there is still little scientific production related to the social paradigm in the field of user studies, which hinders the perception of individuals as active beings and transformers of social reality. It also points out the insertion in the social paradigm of Information Science as "the most important transformation by which the studies of information users in the contemporary moment can pass, and perhaps this is the necessary condition for these studies to actually develop a solid theoretical foundation." (Araújo, 2010a, p. 27).

\title{
3 Information practices
}

The term information practices has its first appearance in the literature of information science inserted in the studies of information seeking, still in the decades of 1960 and 1970. Savolainen (2007) emphasizes, nevertheless, that a more detailed and deep discussion of this concept has been made from the first decade of the twenty-first century, that is, about sixteen years ago.

Although there isn't a unique concept, some authors have developed ways of explaining the meanings of information practices. Marteleto (1995) and Araújo (1999), for example, consider that any social practice is an informational practice, "an expression that refers to the mechanisms by which cultural meanings, symbols and signs are transmitted, assimilated or rejected by actions and representations of social individuals in their established and concrete spaces of achievement." (Marteleto, 1995) The author defends this definition in historical societies as the current one, in which "the production and reproduction of the cultural artifacts happens by the informational way".

According to Araújo (1999), information practices are conceived by individuals who adopt a posture that runs through two paradigms of Information Science: the cognitive and the social one. The influence of the cognitive paradigm is on the need to perceive the origin of the individual previous experiences, while the social paradigm is based in considering the cultural context where the person is inserted (Medeiros, 2005, p. 48). 
It should be noted, therefore, that a complete analysis of information practices requires the person and his / her relations with the world to be considered, while at the same time the subjectivity of the individual must be recognized. This point of view recognizes the socio-historical character of the subject, which is constituted based on interests and conflicts of his / her social class and, therefore, influenced by political issues (Azevedo \& Marteleto, 2008).

Azevedo and Marteleto $(2008,278)$ point out limitations in the work that was being carried out by Information Science. For them, the error of considering the subject as a universal and a-historical being was constant, "emphasizing more the psychological and individual dimension of the subjects, to the detriment of their cultural and social attributes and their collective actions." In addition, they assume the difficulty of researchers in recognizing that "each social group builds a common consciousness that structures its information practices", which is presented in a way implied to members, not necessarily in the form of writings, rules, and laws.

The authors also identify the term information practices as an element of contextual transformation from the person's actions, recognizing it as

\begin{abstract}
a permanent work of knowledge contextualizing in face of concrete situations, i.e., the value of information is not defined a priori, but based on a situational demand of a particular group, in a given context or sociohistorical situation. Everything depends, to a large extent, on how and from where the situations have been approached and problematized and implies a work of interpretation that is done from different perspectives: by producers, mediators, and users or receivers of the information and in different domains of culture (Azevedo \& Marteleto, 2008, p. 279).
\end{abstract}

To justify this conceptual point of view, some studies have referred to authors considered classic, such as the philosopher Karl Marx (1818-1883) and the sociologist Pierre Bordieu (1930-2002), reinforcing the sociological and contextual perspective of practices (Jouis et al., 2012, p. 420). The work of Nascimento and Marteleto (2004), for example, affirms that the ideas about information practices in the social space have support in the sociology of the culture defended by Bordieu, by which "the social space is structured by the set of actions, representations, and social interactions that the subjects face, but also, it generates and structures the social characteristics of the actors that produce the social practices." (Nascimento \& Marteleto, 2004).

In addition, Pinto and Araújo (2012) identify, in the categories of analysis proposed by Bordieu, elements that favor the understanding of the relationship between individuals, information practices, and society. For them, the sociologist

sought to understand the relations of dispute between dominators and dominated, not only in an economic perspective, but also from the marks that these disputes leave in the subjectivity of the people and that conform their action in face of everyday situations, that is, Bourdieu incorporates the dimension of the symbolic and of the cultural (Pinto \& Araújo, 2012, p. 223).

By referring to the relationship between the dominant and the dominated, it is possible to return to Marx's analysis of the production process prevailing in the capitalist system. The German philosopher claims that the dichotomous conflict relations between the bourgeoisie and the proletariat are caused by class domination. Classes, on the other hand, arise from a differentiated division of labor, with consequent accumulation of surplus production by a minority (Lowy, 1985).

In the context of information practices, Pinto and Araújo (2012) defend the need to understand the user from the conflictual relations generated by the division of classes, promoting an analysis that covers elements such as historicity, totality, and tension. These three elements are highlighted by Lowy (1985) in his studies on world social ideologies and visions, and can be understood as follows:

1. Historicity: principle of analysis of historical development and historical transformation of all institutions, structures, laws, and forms of social life;

2. Totality: the principle of perception of reality as a whole, "in which an element can't be understood ... without losing its relation to the whole" (Lowy, 1985, p.16). 
3. Tension: it is an element that is constantly present in society, developing the role of determining the relations "and the production of meanings among them, between the various groups, segments, and social classes that make culture .... the terrain of dispute for hegemony." (Cardoso, 1994, p. 112).

Perceiving the user from these three elements favors a broad approach, not limited to the context of a particular institution or group. Pinto and Araújo (2012) show, as an example, that, when talking about knowledge management in a company, it is not appropriate to treat employees, managers and employers as equals, since each of the subjects has a set of information specific to their functions, there are "differences in possession of information regarding the place occupied by the person in the company" (Pinto \& Araújo, 2012, p. 225).

Thus, it is noted that the study of information practices today does not present any kind of manuals that guide the researcher along this path. Marteleto (1995) points out that a society such as ours is "permeated by matrices of different and conflicting meanings which are still multiple, competing or superimposed". This context means that the work of identifying and analyzing practices requires constant adaptation of the ways of doing, based on perceived obstacles, and there is a need for careful observation of the factors that interfere (and promote changes) in all elements of the information flow.

Aiming to promote a better understanding of the field's own idiosyncrasies, McKenzie (2003) developed a twodimensional model of information practices directed specifically to ELIS (everyday life information seeking) activities. The author believes that several current research models are basically concerned with promoting the evaluation of active information seeking behaviors, neglecting the search practices that exist in everyday life.

Thus, McKenzie (2003) presents this model, which is inspired by conceptualizations of the social paradigm and not only in the cognitive approach (characteristically adopted in previous studies), based on a study of 19 Canadian pregnant twins. Basically, the two-dimensional model can be understood from four modes of information practices (a, b, c, d) and two stages of information process: (1) connection and (2) interaction as described below.

Information practices modes (McKenzie, 2003, p. 26-27):

a) Active seeking: is the most directed mode of information practice. Accounts of active seeking mentioned practices such as specifically seeking out a previously identified source, conducting a systematic, known-item search, asking a pre-planned question, and planning or employing active questioning strategies (e.g. list-making).

b) Active scanning: involves practices such as semi-directed browsing or scanning in likely locations (for example, doctors' offices or bookstores), systematic observation of physical characteristics or behaviour, identification of opportunities to ask spontaneous questions, and active listening to conversations or questions in likely locations (e.g. group discussions in prenatal classes or multiple birth association meetings). Accounts of active scanning involved the recognition of a particular location as a likely information ground, or of a particular source as likely to be helpful, although the seeker may not describe having an expectation of finding anything specific.

c) Non-directed monitoring: involves serendipitously encountering and recognizing a source (e.g. seeing a father pushing a double baby carriage, finding a book sale) in an unlikely place, while not seeking information at all (chatting with acquaintances), or while monitoring information sources (such as reading the daily newspaper) with no intent other than to become generally informed. Accounts of nondirected monitoring also included incidentally observing informative behaviour or physical characteristics or overhearing (rather than actively listening to) conversations between other people.

d) By proxy: refers to those occasions when participants described making contact with or interacting with information sources through the initiative of another agent, either the information source or some other gatekeeper or intermediary. Because the agent may be using any of the other three modes of connecting with the recipient (active seeking, active scanning 
or non-directed monitoring), accounts of proxy practices are extremely varied in their characteristics. They can include such practices as being identified as an information seeker by an acquaintance or stranger, being referred to a source through a gatekeeper or intermediary, or being given advice, information or prescription.

Information practices stages (McKenzie, 2003, p. 28):

1. Making connections. Considers descriptions of the barriers and practices involved in identifying (or being identified by) and making contact with (or being contacted by) information sources or potential sources, whether directly or through a referral.

2. Interacting with sources. Considers descriptions of the barriers and practices involved during the actual encounter with an information source, once the identification and contact have been established.

The relations among the four modes and the two stages are aimed at preserving the fluidity of the analyzed practices and, at the same time, allowing a systematic description of the practices and the process (McKenzie, 2003, pp. 27-28). The author also believes that, with this conformation, the study encompasses information practices in a holistic way, including the fact that the individual is located within a given context, suffering interference and promoting the construction of meanings.

Savolainen (2007) makes positive comments about the model, since, under the social paradigm, the author considers it capable of placing emphasis on social practices and activities of interaction among people, reproduced in contexts of social routine over time and space. "Focusing on practices rather than on behavior means that the analysis shifts from the cognitive to the social and is consistent with the study of information seekers in their social context." (Savolainen, 2007, p. 122).

The concept of the term context, however, must be conceived in all its complexity. Gasque and Costa (2010) identify that many researches fail to provide a wide dimension to the concept, understanding the contextual question only as a set of physical elements that, in a way, interfere in the information practices of the subjects. For the authors, the appropriate context analysis model must perceive individuals

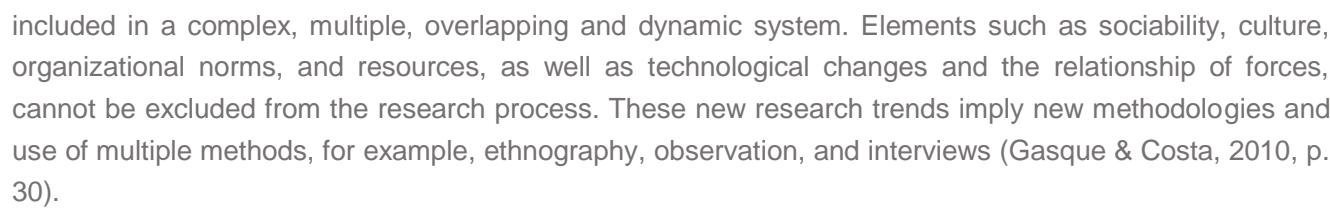

Yeoman (2010) presents the relevance of discussing the context for applying McKenzie's model (2003) in several researches, in addition to the universe of pregnant women of twins evaluated by the Canadian researcher. As reported by Yeoman (2010), the two-dimensional model of McKenzie (2003) failed to fully contemplate the practices identified in her research with menopausal women.

The author, therefore, identified the need to include the concept of information use in this model, allowing the discussion to advance from information seeking and information access to what actually occurs by the interaction of an information subject with sources of information. From the identification of this new need, Yeoman (2010) proposed an extended version of McKenzie's model (2003), which can be observed in figure 1. 
Figure 1. Extended version of McKenzie Model

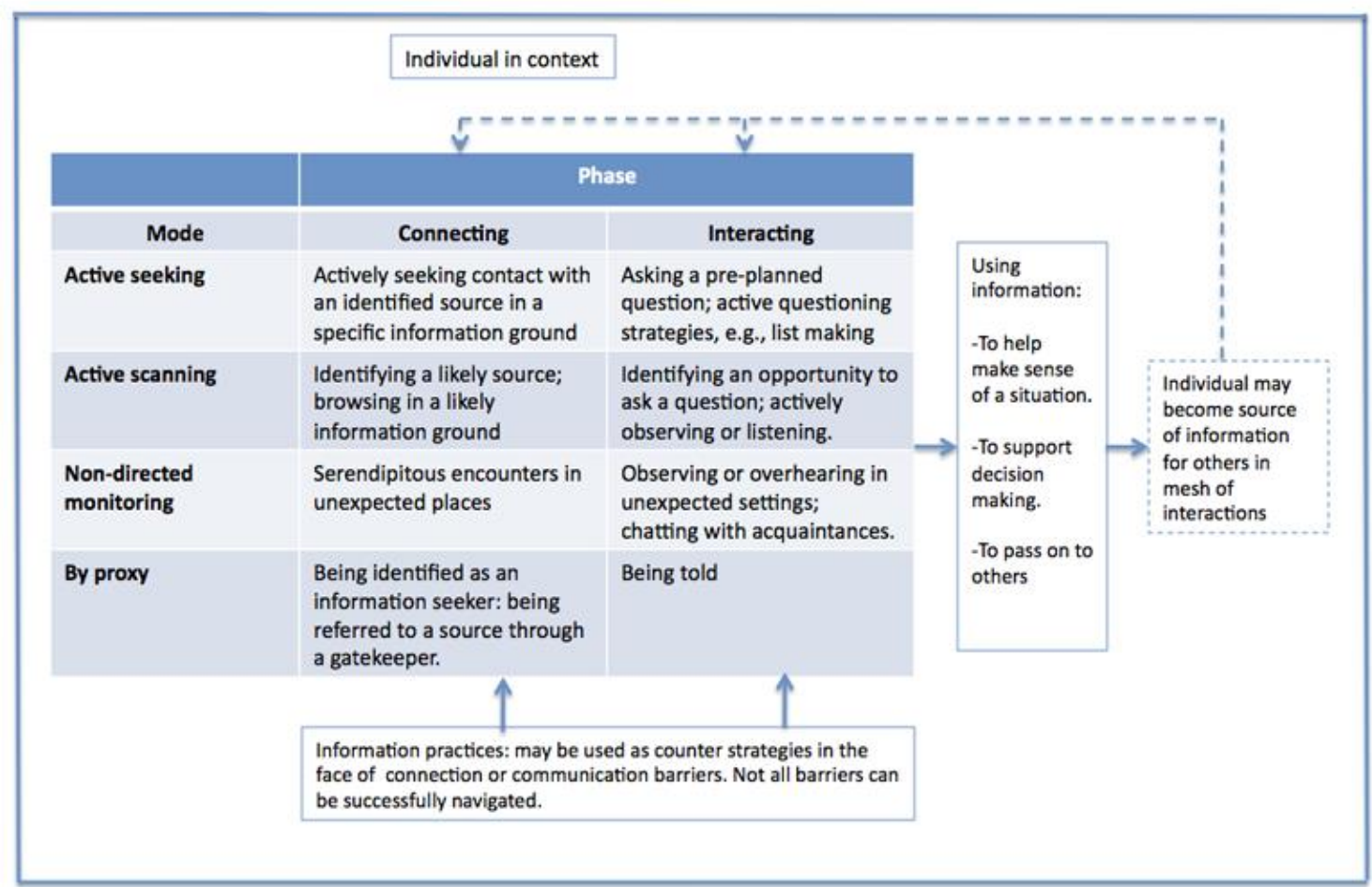

From: Yeoman (2010).

\section{Methodology}

By adopting the social paradigm within user studies, it is not the objective of this research to reach quantitative results that define and systematize, in some way, the analyzed information practices. For the context of this research, we must recognize the individuality of the subjects inserted in a social context, as constructors and modifiers of social reality, according to the theories and models proposed and presented. To achieve these objectives, in addition to the qualitative methodology, semi-structured in-depth interviews were defined as a method of data collection. Thus, although there was a prior script that guided the interview, new questions could be inserted from the answers, in order to obtain a broad perception of the information practices adopted and the context and historicity in which each family investigated is inserted. The method was applied in face-to-face conversations with mothers of children diagnosed with food allergy. It was decided to interview the mothers due to their notoriously greater participation in Internet groups and in reports on websites and blogs. Between April and September 2016, 7 mothers were interviewed, two of whom were mothers of two allergic children. All the interviews were audio recorded for later transcription. The research was previously authorized by the University Research Ethics Committee and all participants signed an Informed Consent Term.

Table 1 presents a summary of the children profile of the analyzed families, based on items such as age, type of allergy (mediated, unmediated or mixed) and foods causing allergy. Families are identified from numbers and children from letters to maintain their anonymity. The age present in the table corresponds to the age the child had at the time of the interview with the mother. 
Table 1. Children profile of the families interviewed

\begin{tabular}{|c|c|c|c|}
\hline Family & $\begin{array}{l}\text { Age of child } \\
\text { with allergy }\end{array}$ & Type of allergy & Food that cause allergy \\
\hline 1 & $\begin{array}{l}\text { Child a: } 4 \mathrm{y} 10 \mathrm{~m} \\
\text { Child b: } 1 \mathrm{y} 6 \mathrm{~m}\end{array}$ & $\begin{array}{l}\text { Child a: unmediated } \\
\text { Child b: mixed (presented } \\
\text { mediated e unmediated reactions). }\end{array}$ & $\begin{array}{l}\text { Child a: milk, soy, egg, oilseeds, red meat, } \\
\text { and tomato } \\
\text { Child b: milk, soy, egg, oilseed, red meat, } \\
\text { and banana }\end{array}$ \\
\hline 2 & Child c: $2 y$ & $\begin{array}{l}\text { mixed (presented mediated } \\
\text { reactions until } 1 \text { year old) }\end{array}$ & Milk and soy \\
\hline 3 & Child d: $2 y 6 \mathrm{~m}$ & mediated & Milk \\
\hline 4 & $\begin{array}{l}\text { Child e: } 4 \mathrm{y} 10 \mathrm{~m} \\
\text { Child f: } 2 \mathrm{y} 5 \mathrm{~m}\end{array}$ & Child e: unmediated & $\begin{array}{l}\text { Child e: Milk, soy, peanut, soy lecithin, } \\
\text { soybean oil, wheat (sensitized), and corn } \\
\text { Child f: Allergic to all foods except: } \\
\text { pumpkin, chayote, yam, zucchini, pear, } \\
\text { peach, plum, rice, chicken broth and sweet } \\
\text { potatoes }\end{array}$ \\
\hline 5 & Child g: $10 y$ & mediated & Milk \\
\hline 6 & Child h: $5 y 6 m$ & mediated & Milk \\
\hline 7 & Child i: 1a3m & $\begin{array}{l}\text { mixed (presented mediated and } \\
\text { unmediated reactions). }\end{array}$ & Milk and egg \\
\hline
\end{tabular}

Developed by the authors from collected data

\section{Results}

After completing the interviews, all were transcribed integrally in Microsoft Word files, font Arial, size 11, spacing 1.5. A total of 128 transcript pages were obtained. From the collected data, the analysis of the transcribed content was carried out, using the technique of grounded coding, with constant comparison, that generated a final set of 16 codes.

The results show that it was possible to identify at least 12 of the codes in each family (see table 2). Although each informational practice has its own characteristics, according to the contexts that make up the life of the mother interviewed, the creation of codes allows organizing the comprehension of the phenomenon to better studying it.

Table 2. Codes identified in the information practices of the families interviewed

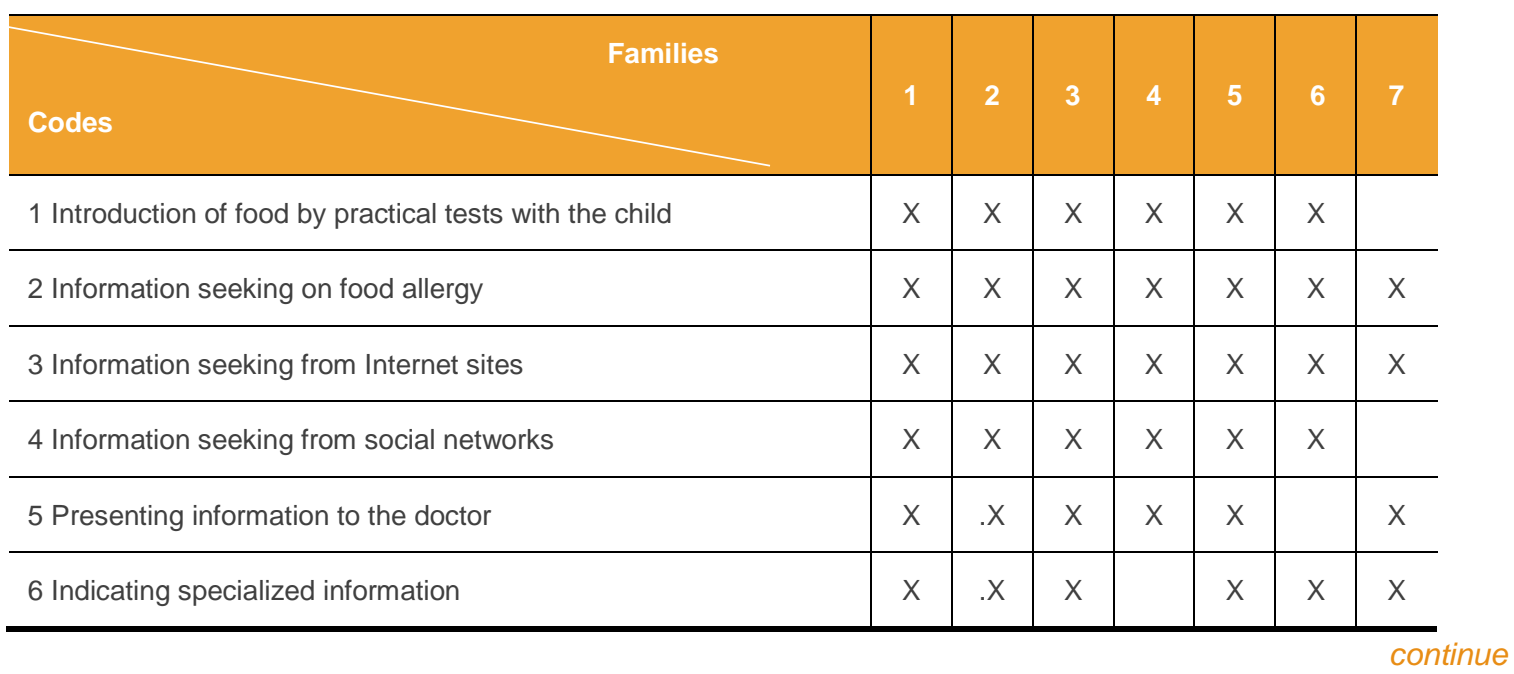


Table 2. Codes identified in the information practices of the families interviewed (continuation)

\begin{tabular}{|c|c|c|c|c|c|c|c|}
\hline Families & 1 & 2 & 3 & 4 & 5 & 6 & 7 \\
\hline 7 Attempt to diagnose from practical tests and observation & $x$ & $x$ & $x$ & $x$ & & & $\mathrm{X}$ \\
\hline 8 Attempt to diagnose from the identification of symptoms & $\mathrm{X}$ & $\mathrm{X}$ & 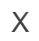 & $\mathrm{X}$ & $\mathrm{X}$ & $x$ & $\mathrm{X}$ \\
\hline 9 Information obtained in daily actions & $x$ & $x$ & $x$ & $x$ & $x$ & $x$ & $x$ \\
\hline 10 Food labels and contact with Customer Service & $X$ & $X$ & $X$ & $X$ & $x$ & $x$ & $X$ \\
\hline 11 Suggestions about food allergy from third parties & $X$ & $X$ & $x$ & $x$ & $x$ & $x$ & $x$ \\
\hline 12 Specialized information from third parties & & $X$ & & & & & \\
\hline 13 Information on scientific studies about food allergy & $X$ & $X$ & $X$ & $X$ & & $x$ & $X$ \\
\hline 14 Attempt to adapt from acquired knowledge & $x$ & $x$ & $x$ & $x$ & $x$ & $x$ & $X$ \\
\hline 15 Mother acting as source of information & $x$ & $x$ & $x$ & $x$ & $x$ & $x$ & $X$ \\
\hline 16 Information sharing among mothers of allergic children & $X$ & $x$ & & $x$ & $x$ & & \\
\hline
\end{tabular}

Developed by the authors from collected data

It is worth noting that the fact that a particular code is not identified in a family does not indicate that the mother of this family does not perform such an information practice in her daily life, since it is not possible to apprehend all the practices adopted by the family in only one interview. The result indicates that, specifically in the analysis of transcribed content after the interview, such practices were not observed. This question is directly related to the characteristics of the research, which had the analysis codes defined a posteriori, according to the analysis of the transcribed contents. It is believed that the definition of these analysis codes prior to the interview would be immature, since at each conversation it was possible to understand new nuances and perceive various issues on the topic of food allergy.

Thus, throughout the interviews, no attempt was made to obtain examples of specific analysis codes, since they were not yet defined. What is clear, however, as the mothers themselves reported, is that each family finds its ways of dealing with food allergy.

Finally, to reach the research objectives, we sought to associate the codes resulting from the data analysis the categories of the models of information practices studied (McKenzie, 2003; Yeoman, 2010). This was done by inserting the codes in the original model figure, that is, by classifying each code into an information seeking mode/stage of McKenzie's pair or to a category of Yeoman's information use, as shown in Figure 2. In the following sections, we explain the reason for the classification of each code in a certain category of the model. 
Figure 2. Association of results to the McKenzie and Yeoman models

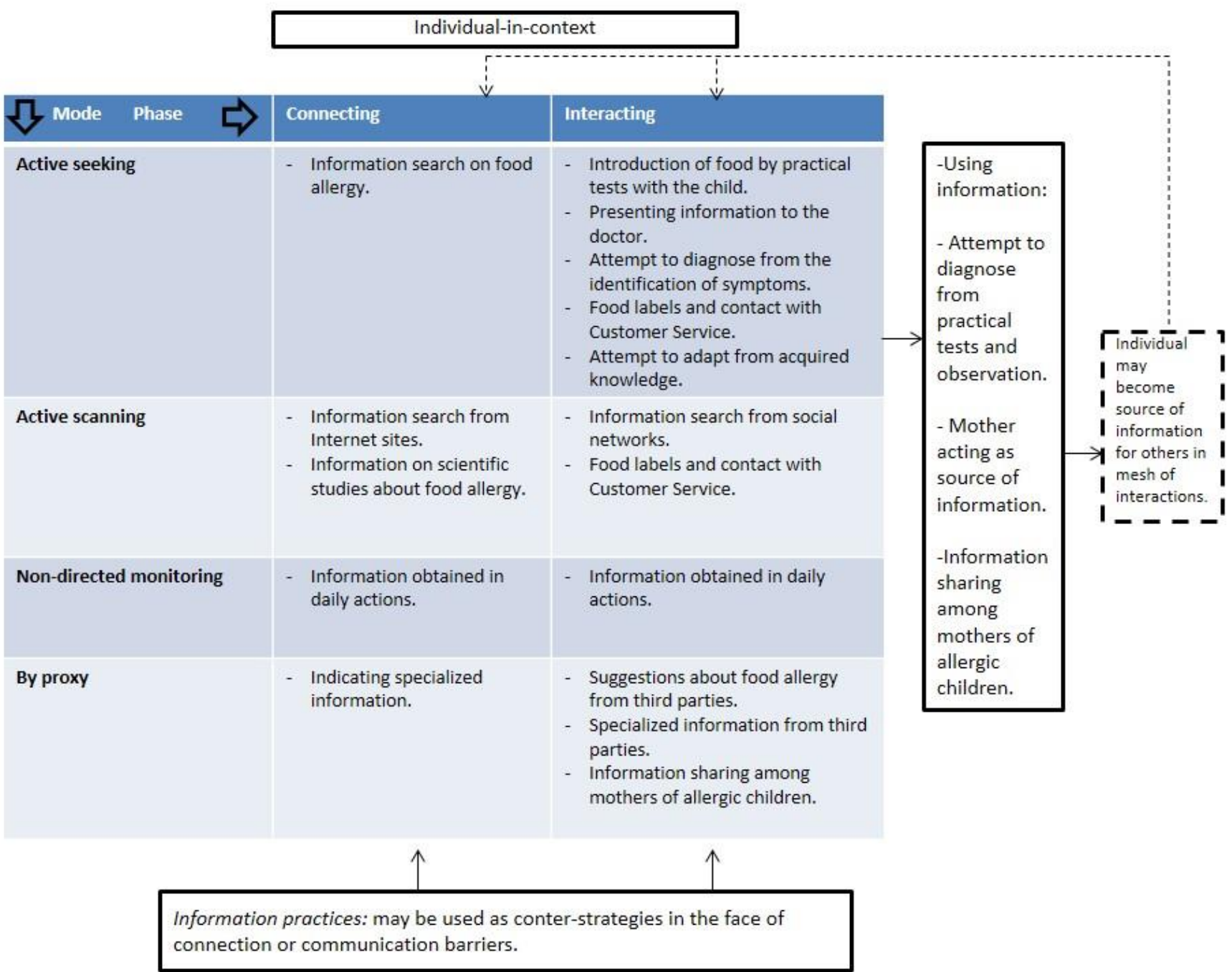

Developed by the authors from Yeoman (2010).

\subsection{Introduction of food by practical tests with the child}

After the diagnosis of food allergy, at first mothers do not know exactly what foods cause allergy, especially when the child is not mediated (in mediated allergy, it is possible to identify the allergen from specific tests, although, for children up to two years old, false negative results are common). Thus, information practices related to mothers' attempts to identify exactly what foods that cause the allergy and how much of them are supported by the child's organism were perceived.

Some examples are:

I tried to introduce cauliflower and he reacted. But it does not mean he's allergic, maybe, at that point, he was not ready yet. Because there is a whole change in the immune system, digestive system, and such. This happened with the sprinkles. I tried once, and he had a reaction. After a few days I tried, and it was all ok.

In day-to-day life, we can notice the difference. Before, I did not give him salt bread, French bread, that scared me to death. French bread does not have milk, but it can contain traces of it, right? Then I started to give a little piece so small, such and such. Today he already eats one loaf, two loaves a day. Nothing happens at all.

Considering that it is not possible to obtain this information from medical or laboratorial exams, the families choice is to make tests and, on a daily basis, to develop responses to the symptoms presented by the children. 
This code, therefore, presents information practices essential in the elucidation of foods that are allergenic to a child and, consequently, in the search for better life quality. In the models adopted, it is located as an active information seeking mode and in the interaction phase, since it corresponds to active strategies of questioning by the mother.

\subsection{Information seeking on food allergy}

Whenever there are symptoms of a disease, the most common is to seek medical attention to receive guidelines and treatment indications. Thus, this information practice portrays exactly one of the first actions of any mother when realizing that there is something wrong with her child: the search for specialized information.

What is perceived in the mothers' reports, however, is that the doctors had difficulty in reaching a diagnosis. And even when there is a diagnosis of food allergy, it can be noted that doctors are inefficient in presenting all the information necessary to control the symptoms. One mother commented that "what most doctors fail to accept is that what is for one is not for another. And I've seen, for example, allergic children who can even take yogurt. [...] I was once at an allergist who said: your child is not allergic." Even with these difficulties in choosing the doctor, however, it is noticed that, at a certain point, families can find a specialist who satisfies them and respects the opinions expressed by the mothers. One mother, for example, remembered that she went through seven different doctors until she found a professional who pleased her.

Thus, we can perceive the need for identification of a health professional to provide reliable information to families. Even with this, however, one of the interviewees defends the need for constant observation of the child by the mother. She highlights, for example, the existence of a pattern in differentiating an allergic reaction from the flu: "Only the mother can really see it, not even the pediatrician can understand."

In the information practices model, this code is inserted as an active search mode and in the connection phase, since the mother acts actively in the search for information and searches the source in a specific informational field (in this case, in the medical area).

\subsection{Information seeking from Internet sites}

Faced with the appearance of food allergy symptoms and some difficulties to receive the medical diagnosis, some of the interviewed mothers reported having searched the Internet on the subject. One mother says she discovered the allergy using Google.

I wrote everything he had on Google. I made a gigantic list, I think I have this list until today. I thought and wrote down everything he had, everything. No, it does not make sense for a 4-month-old to have it all. I took everything that was on the list and inserted it on Google, with no comma, only space. I just tried. Then came the report of the mother of an allergic child.

Another mother says she recurred to the internet just after receiving the diagnosis of food allergy at the hospital. Her child had an anaphylactic shock from drinking milk.

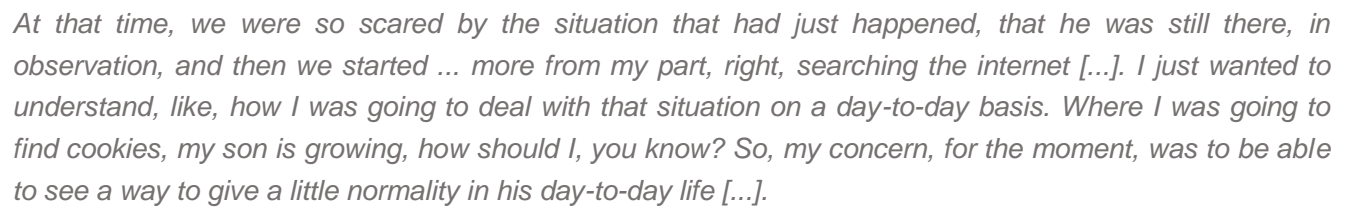

In this report, it is possible to perceive the concern of the mother to seek a quality of life for the child, being the Internet search one of the ways that the families find to obtain more information and to adapt the routine.

Because it is a search on probable informational terrain (obviously requiring filtering of the large amount of recovered content), the information seeking form Internet sites is inserted into the active scanning mode and in the connection phase of the analyzed model.

\subsection{Information seeking from social networks}

Although the search in virtual social networks was also part of the search in the Internet, it was decided to differentiate them from other sites, due to the relevance and prominence they acquired in the interviewees' 
speech. The existence of Facebook groups for the exchange of information on food allergy was highlighted. One mother said that "the group is excellent, it saved my life several times".

Another one feels for not having known the group since their children were babies: "I did not have a group of mothers yet, which made all the difference in my life." The same situation occurs with a third mother, which said: "If I had entered this group when he (the son) was a year, two years old, my life would have been another. I would have had much more quality, I could have gone out more [...]."

In one of the families investigated, the interviewee stated that

Before (of the group on Facebook) was knowing nothing. Then God knows how he's still alive (laughs).

Because we simply had the doctor's orientation, and he said he could not consume traces, anyway ... so what? What does this mean, have no traces? [...] these groups have helped us a lot with allergy.

Through the models, the code was classified in the active scan mode and in the interaction phase, since the groups appear as an opportunity to ask questions and to observe about the food allergy.

\subsection{Presenting information to the doctor}

From the research carried out with the mothers, constant observation of the children's reactions, and the very feeling of these women, a code was identified that includes information practices in which mothers present to physicians certain information that contributes to the diagnosis, care, and treatment of food allergy.

After analyzing the interviews, the importance of the active participation of these mothers during the medical visit is clear, trying to find answers to the symptoms that afflict their families. A mother reports that she herself told the doctor that it could be a food allergy: "I even suggested to his doctor, the pediatrician who was accompanying at the time, I suggested ... can't it be allergy?" Another one also recalls a similar situation:

It was me who proposed "let's take out milk from his diet". The allergist who was accompanying him at the time, [...] I told her that I thought the milk was giving him the reactions, she was like this, "Do you think so?" So, I answered: "He coughs after he drinks it, it's not normal, there's something in his throat that's bothering him".

Some mothers also had to deal with presenting information to the doctors and receiving resistance from them.

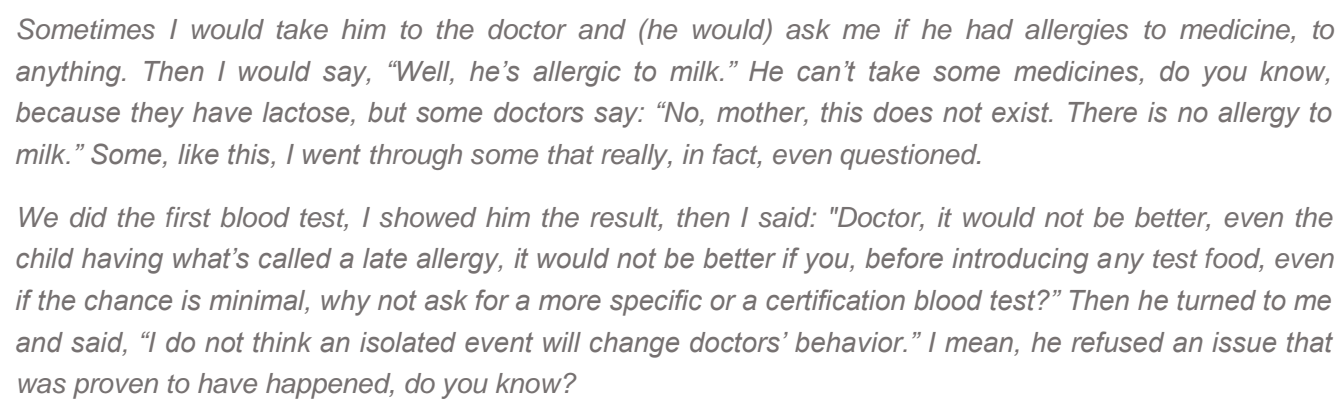

This information practice was classified in the active information seeking mode and in the interaction phase, since the moment of the medical consultation is presented as a moment to ask questions, based on the elements observed by the mothers in the children's daily life.

\subsection{Indicating specialized information}

Throughout the process of understanding and accepting food allergy, it is common for families to receive indications of specialized information on the subject from other mothers or even from physicians.

So, you will need to find a doctor who understands and such. She (another allergic child's mother) told me to look for Dr. $x x x$, which is the best.

Then she (the doctor) managed to fit us into a following-up program that the public health system has.

[...] We also had the suggestion of a doctor, in Belo Horizonte, who usually does this treatment.

The mode of this category is by proxy and the phase is the connection, where mothers are recognized as searchers for food allergy information. In this case, an intermediary (another mother of an allergic child, an 
acquaintance, a health professional, among others) tries to present information sources that interest these mothers.

\subsection{Attempt to diagnose from practical tests and observation}

Aiming to identify which foods cause allergic reactions in the child, many families need to perform practical tests on a daily basis. One mother said that from a list of six allergens described by the doctor, she had to remove all from her own diet, since she was breastfeeding and needed to stabilize the child's allergic condition. After total foreclosure, she decided to reinsert one by one in order to know what foods she really could not give her son.

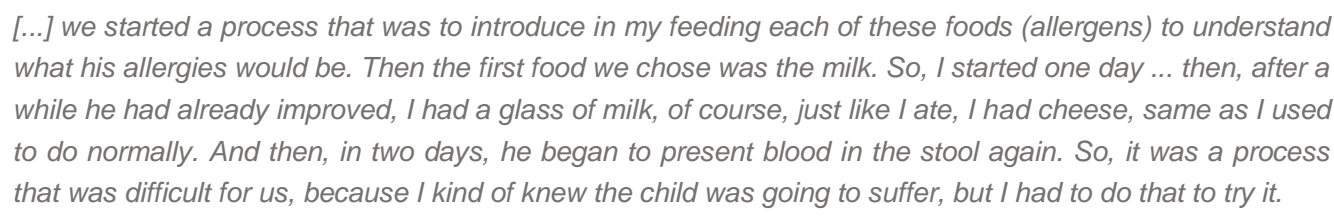

Another mother carried out a food diary of the child to identify which of the foods consumed had caused an allergic reaction and the pattern of the symptoms. She says it was important to make a food diary because she could establish the reaction time the child had. She said, "That's when I found out ... ah, he reacts in 48 hours, it's not 24, it's not 72. It's 48."

In the model of information practices, this code is inserted in the category "use of information", added by Yeoman (2010), specifically in the first two uses indicated, which are: to help make sense of a situation and to support decision making. It is observed, therefore, that mothers produce information that will be used by themselves in their daily lives.

\subsection{Attempt to diagnose from the identification of symptoms}

Diarrhea, reflux, colic and dermatitis are the main symptoms cited by the mothers interviewed. Initially, however, the presence of these symptoms on a day-to-day basis is not perceived as a food allergy by families and, as can be seen in some of the cases analyzed here, not even by physicians.

However, in the mothers' interviews, it is clear that they perceive that there is something wrong with the child and do not give up seeking a diagnosis from the identified symptoms.

\footnotetext{
In the first three months, you go to the doctor, the doctor says: "it's normal." Everything is normal, everything is adaptation. Before three months, the child is gushing out in pain. "Oh, it's colic, it's normal." His skin is all blistered... "Oh, it's hot, it's normal." But he's squeaking ... "Oh, it's normal for a kid to get virus." Everything was considered normal.

I, not accepting: "it is not possible that this is only reflux!" He didn't have any clothes in his closet, they were all in the buckets. It was a poop after another, he was always dirty. We had to buy clothes for him to use, so much poop he did. He vomited without stopping.
}

The identified mode is the active search and the phase is the interaction. In the case, from the identified symptoms, we have an information that is presented as an active strategy of questioning.

\subsection{Information obtained in daily actions}

Some information that mothers have about food allergies have not been obtained through doctors, acquaintances, or the internet. Much of what these families learn about how to deal with allergic symptoms occurs in practice, from moments of everyday life, which also constitute a form of information practice. One mother reported how she realized that the child had reactions from the smell of allergenic foods:

I, not accepting: "it is not possible that this is only reflux!" He didn't have any clothes in his closet, they were all in the buckets. It was a poop after another, he was always dirty. We had to buy clothes for him to use, so much poop he did. He vomited without stopping.

Another mother related the onset of allergic reactions to red meat consumption by the child. She reported that: 
I had to remove the red meat out of his meals because I saw that he [...] did not sleep at night, and he would one day eat chicken, one day red meat. So, he slept a better night, a bad night. I kept watching him all the time.

Then I picked it up and took out the red meat, and he improved a lot.

This practice was classified in the non-directed monitoring mode. Regarding to the phase, it is possible to include this category both in the connection (where information is obtained unexpectedly and without planning) and in the interaction (when something is unexpectedly known from a conversation with someone known). In the cases cited, the mothers were not in the doctor's office or reading a scientific paper on the subject, for example, but in day-to-day situations with their children.

\subsection{Food labels and contact with Customer Service}

The tenth code to be detailed deserves detailed mention due to the importance that the subject of food labeling has gained since 2015. As presented, Anvisa approved a labeling regulation for allergens and provided a deadline until June 2016 for food companies to promote the packaging adaptation.

Only one of the interviews was conducted prior to this deadline. The other reports have already presented experiences before and after the change in the labels. Prior to the mandatory identification of allergens, one way that mothers had to obtain information about food was to call or email Consumer Services. One mother stated that "[...] this contact with Consumer Service is very difficult, but nowadays they are better prepared, it is better than it was a while ago, but there is still a lot to be done."

Another mother said that when she contacted Consumer Services, she used to send e-mail. "[...] When it's by email, sometimes I trusted more, you know? [...] You would ask one day, it's one thing, you asked in the other, it is another. There's no penalizing mechanism, right?'

Another mother is also careful to deal with the matter: "Now it's more reliable, but... there are many products that are still old packages, so, you still have to wait a little, right? You can't be totally relying on it, yet."

The experience of a family shows how much the change in regulation was expected by these mothers, as follows:

This change in food labels is everything we've always dreamed about [...] I can't believe it's like this, that it's on the label: "allergic, it contains ...", this is a security. Let's put like this, for us, there were two moments: one when we did not know that this existed, that we bought and consumed by ignorance. Thinking that it didn't have, or not knowing if it did, by ignorance. We took a risk, or sometimes the child had reactions without knowing, due to the lack of knowledge. There was a time between knowing that it existed and the law not having been effectively enforced, that we began to restrict a much larger number of foods. We basically split it up like this: what is bought at the fair can be eaten, what is bought from the supermarket can't.

This code can be included in both the active search mode and the active scan mode, both in the interaction phase.

The active scanning occurs when the mother arrives at the grocery store and begins to read food labels, for example, looking for some product that is appropriate to the nutritional needs of her child, actively watching the options found. It may correspond to a first moment of contact with food allergy, where the family does not yet know the brands allowed for consumption, and it is necessary to scan the labels available.

In the active search, in turn, the information practices involve active strategies of questioning: the mother knows what she is looking for in the packaging and what she wants to ask the consumer service attendants. It may correspond to a time when the family is adapted, where it is already known exactly which foods cannot be consumed by the child and there is already some knowledge about the brands released for safe consumption. Even so, however, attention is paid to possible changes in the ingredients and to new foods that are available on the market.

\subsection{Suggestions about food allergy from third parties}

In the search for diagnosis, many mothers received suggestions from relatives, friends, and / or acquaintances who tried to help solving the symptoms presented by the children, as can be seen in the following reports. 
Desperate to solve the plight of infants, two mothers show that they even tried some of these guidelines received by others, without success.

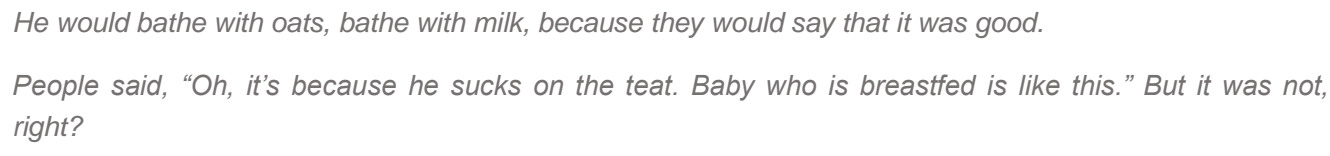

Each one says something. To cut off chocolate, to cut off coffee, to cut off the most absurd things, and always stays like that: "oh, this is common, babies have colic.".

Other mothers say that instead of receiving help, they have been judged, for example:

\begin{abstract}
A lot of people think it's choosy from me. "Oh, she has an allergic son ... Oh, what a boring thing, it sounds like he is the son of a queen. She is poor and the boy has the disease of the rich." It's not like this, I did not choose my child to be born with food allergy.
\end{abstract}

In the information practices model, this item can be perceived as a by proxy mode and interaction phase. In this case, mothers receive advice on food allergy unexpectedly, in some daily conversation, without them looking for something related to the matter.

\title{
5.12 Specialized information from third parties
}

This code differs from the previous one because it refers to specialized information on the subject. The situation that generated the creation of this code is below:

\begin{abstract}
At the campaign season, we can apply to the health department, they send the special vaccine for the allergic kid. It started with a lady from the health center here who talked to me, unintentionally, and it was not my idea. It was the lady who was really cool. There's a woman running in the vaccine campaigns. She runs the health centers to help. So, every 2, 3 months, she stays at a different center. And she was on this center here. I had not seen her before, and I explained: my son is allergic, here is his file, there is his number, his medical records are there. She told me: We need to make a request - I had never done it - of the different vaccine, and she did not know anything about how to do it. This lady was so cool that I think she called the whole world, she found out how it worked, found out what it was, discovered what allergy was, and made the specific request directly to the health department. I do not even know how she did it, how she made a direct contact with the health department to be able to send the vaccine to us. She called me, she called me like this, every time, to know things, asking ... The day the vaccine arrived at the center, she called me: look, there are 10 doses. Would you know any more moms, are there kids you know with the same problem? Let's bring everyone together. Otherwise we will have to throw away the other doses of the vaccine.
\end{abstract}

In this case, the mother obtained new and specialized information on the subject unexpectedly. When she attended the health clinic, she did not expect to find out about the need for a special vaccine for allergy sufferers. Therefore, this information practice can be included in the by proxy mode and in the interaction phase.

\subsection{Information on scientific studies about food allergy}

Throughout the interviews, mothers were interested in studying scientific works that address the issue of food allergy. One mother said that studying issues of interest is routine at her home. "This kind of thing has always been one of my mother things, because she's always been the book-crazy one, do you know? Now we all research ... we want to find out what's in the background, to know things in depth."

Another mother said that the physician who accompanies her child is one of the people who encouraged her to read more about it. "The doctor who takes care of him also gives me a lot of papers to read. And so, I research like this: the last thing that came out in the Brazilian Association, [...] we are studying."

This code is presented as an active scan mode and connection phase, in which the mothers identify probable sources of information and conduct research from them. 


\title{
5.14 Attempt to adapt from acquired knowledge
}

The concept of adaptation acquires unique value for these families, since they need to promote changes in their home, to think about new ways of cooking, and to change socializing routines, such as in restaurants, birthday parties, and trips, for example. Here are some examples:

\begin{abstract}
My search for adaptation had begun. When I tell everything I took from the diet, people tell me: what do you eat, wind? Chayote, water? But I made cake with cauliflower, I made salty pie, bread with cassava. I needed to keep my diet as rich as possible so I could take it, right? Because otherwise, it's very easy for us to think about quitting.

I come in, I talk to the people, and when the waiter does not know the answer, the cook comes to talk to me, you know? I ask everything, because the staff is used to use too much butter in everything, so I ask, "But he's allergic, do you take the responsibility?" [...] Then the people go there and tell the cook to talk to me. But there are some places that I have already released, where I already know that I can trust.

Our first trip to a hostel was recent. And it was super fine. He was already asking to go to the restaurant, he sat down with his own packed lunch and called me, asking to speak in secret. The secret was if he could take the juice from the restaurant, from the inn. Then I ordered an orange, cut it with his own knife, squeezed it and he felt happy.
\end{abstract}

This code can be categorized as an active search mode and interaction phase, where there are active strategies for questioning. The aim is that, from the acquired knowledge, these families will understand the adaptations necessary to promote a better quality of life for the children and put them into practice.

\subsection{Mother acting as source of information}

In addition to sharing information to obtain useful knowledge, many mothers also share information to help other families, simply because they have already gone through a similar situation. One mother explained that among mothers of allergic children, a cycle occurs: "one mother helped me, then I helped several others, so like that, as you gain knowledge, we have to divide into the responsibility to help each other."

These families realize the importance of information for the child's well-being and family balance. This recognition is one of the causes that motivates them to act as a source of information.

It is an information practice perceived in a singular way. Since a mother acts in all (or in most of) the modes and phases proposed by the model, she develops the capacity to act as an information source, once she began to understand the theme in a broader and deeper way, due to the information practices she adopted to overcome the observed information needs. Thus, as an information source, she promotes stages of connection and interaction with other individuals, to pass on information, generating a collaborative network among those involved, becoming, therefore, as a source of information to pass on to other people and then promoting information use.

\subsection{Information sharing among mothers of allergic children}

The mothers emphasized the relevance of the information exchange among themselves as a way of deeper learning on the issue.

One of them stressed the opportunity to ask questions to women who went through similar situations as hers by pointing out that "what helps more with respect to the media, no doubt, is our group on Facebook. It's the girls. [Name], any questions I call her, she responds. She is always willing to help [...]."

For another mother, who had depression after her child's food allergy diagnosis, sharing information with other women provided another insight into the issue.

You think it's just your problem, do you know? When you find out something, you think, "wow, this is happening to me alone." Then, when I started to join the groups that I found, I said: "Folks, my son has nothing!". [...] His problem was only milk. And then, with the intimacy with these people I ... you start to see your problem so small. You say: God, this is so small, and I was so worried, see?

Often, these mothers share information that was not made available by physicians during a medical appointment. One of them told that important learnings about how to deal with food allergies were provided by another mother. 
I talked to another mother of allergic child: "Your son is allergic, isn't he? How do you do, can you tell me?" So, when she was telling: "Wow, this is just like my son!" I asked: "what should I do?" Then she gave me the first directions: "You will need to buy everything for your house." She gave me some basic teachings about traces, things like that.

Sharing information can occur face-to-face, through social networking conversations such as Facebook, or through private messages in Messenger and through WhatsApp.

There is a mother from São Paulo, she is my reference, I think she knows too much, she always helps me, you know? We talk inbox, I send her a message, she gives me tips.

I discovered a friend there in Pato Branco, in a social network, that her boy was very like mine. Any industrialized stuff I bought, I called her. "Hey, have you given that? Did your boy eat that stuff?" [...] That was my reference, because the insecurity was so great.

In general, the importance of sharing information among the mothers of allergic children to achieve quality of life is perceived. In McKenzie's model adopted, this code can be included in the by proxy mode and in the interaction phase, where mothers receive information about the topic that interests them from the contact they develop with other women. In addition, it is possible to also include it in the three uses of information extension proposed by Yeoman, information use that is passed on to others.

\section{Conclusion}

From the methodology adopted in the research, some of the information practices adopted by the mothers of children with food allergies were identified, and these practices were analyzed under the social paradigm of Information Science. The analysis evaluated the social and contextual aspects of the families interviewed, based on the construction of a dynamic and flexible script that allowed stories and memories to be told in detail, giving space to the whole set of social relations. Thus, from the transcriptions, it was possible to perceive some of the actions carried out by families to guarantee the quality of life and food safety of allergic children. It is considered, therefore, that the general objective of the research was achieved. Regarding the three specific objectives, it was observed that they were also approached broadly and positively, both for the Information Science field and for the families that are concerned with the food allergy issue.

The first objective was to discuss possible relationships between the information practices adopted by mothers of children with food allergies and the maintenance of quality of life and feeding security. This research pointed out the relevance of the mothers' information practices for the stabilization of the allergic symptoms and consequent increase of the well-being of the child. From the information obtained by mothers through medical care, internet research, conversations with other people, among other categories of analysis identified in the research, it is possible that these families have a greater informational framework to deal with allergy issues, helping to improve the child condition. Thus, there is an intrinsic relationship between the mothers' information practices and the guarantee of feeding safety.

Throughout the research, it was also possible to know the processes of information seeking performed by the mothers to offer their children a correct feeding, corresponding to the second specific objective. The birth of the children is very much expected by the parents and, when realizing that the child presents with specific discomforts and symptoms, a moment of disturbance and perplexity is initially noticed. Then, a process of searching for the causes of these concerns begins.

Through interviews, some of the information practices of these families were identified and it was possible to perceive some of the ways found by them to understand the theme. Although similar practices were observed, each family reacted in a way to the news, presenting specificities according to the social, economic, and contextual characteristics that permeate them.

In some cases, for instance, mothers have not received support from their husbands, other family members, or friends since the beginning. In others, this support occurred from the beginning, strengthening the process of searching for information within that family nucleus. For some mothers, contact with other families of allergic children occurred since the diagnosis or even the suspect of it, while for others it took years to occur.

Often, mothers showed satisfaction to know that the issue is being investigated in this research. Through their speeches, it was perceived that the issue is still little recognized, even by doctors. And by the society there is still an idea that allergy is "fussy", or, also, it is confused with food intolerances. 
The sense of urgency to inform the society about the reality of these families strengthens the results of this research. It is hoped that this work will be useful both for the development of Information Science and for families who pass or who will go through the issue of food allergy in their daily lives.

In Information Science, the major contribution refers to the relation of information practices and the codes identified from them to the two-dimensional model of McKenzie (2003) and the extended version of Yeoman (2010). It was possible to observe the existence of each mode and each phase proposed by these models, helping in the confirmation of their relevance to the area. It is noteworthy that, until the present moment, no other Brazilian research has been known that has made practical application of these models for data analysis.

It is also worth noting the recognition of the individuals analyzed, in this case, the mothers of allergic children, as beings that act as sources of information, an item proposed by the extended version of Yeoman (2010). It is notorious that these women, by acquiring knowledge about food allergy, pass this information on to other families as a way of assisting in the process of adaptation. Through the interviews, it was observed that the mothers seek to help other people so that other families suffer less than they suffered from a diagnosis difficulty, for example.

Although the objectives of the research were achieved, the limitations found throughout the study are recognized. Among them, there is the time interval defined for the analysis of the theme, which presents the history of food allergy in the last two years, mainly. This choice was due to changes in the labels required by the new Anvisa regulations in 2015. It is therefore suggested that new studies should be carried out from other time gaps. Another limitation of the research refers to the majority of the middle-class people among the families interviewed. Although the search was performed in several spaces, most of the mothers located by the interviewer belonged to social classes with medium and high family incomes. There is a suspicion that, unfortunately, many of the low-paid families who have children with food allergies do not even get a correct diagnosis. We believe that this question alone should be the subject of an upcoming study.

Finally, we suggest more in-depth studies on information practices, mainly visualizing the user as an active subject that acts as a source of information. By participating in these interactions, in addition to impacting other people's lives, these subjects construct and modify their own realities.

\section{References}

Agência Nacional de Vigilância Sanitária (2014). Alimentos e alergia: participe da Consulta Pública. Publicado em 12 de agosto de 2014. Retrieved May 13, 2015 from http://formsus. datasus.gov.br/site/formulario.php?id aplicacao=16061

Araújo, C. A. A. (2008). Estudos de usuários: pluralidade teórica, diversidade de objetos. Paper presented at IX Encontro Nacional de Pesquisa em Ciência da Informação, São Paulo, SP, Brasil. Retrieved May 19, 2017, from http://enancib.ibict.br/index.php/enancib/ixenancib/paper/view/3027/2153

Araújo, C. A. A. (2010a). Abordagem interacionista de Estudos de Usuários da Informação. PontodeAcesso, 4(2), 2-32. Retrieved September 21, 2015, from http://www.portalseer.ufba.br/index.php/revistaici/article/viewArticle/3856

Araújo, C. A. A. (2010b). Estudos de usuários conforme o paradigma social da ciência da informação: desafios teóricos e práticos de pesquisa. Inf. Inf., Londrina, 15(2), 23 - 39. Retrieved August 13, 2015, from http://www.uel.br/revistas/uel/index.php/informacao/article/view/6485

Araújo, C. A. A. (2012). Paradigma Social nos Estudos de Usuários da Informação: abordagem interacionista. Inf. \& Soc. :Est., (22) 1, 145-159, Retrieved August 14, 2015, from http://www.ies.ufpb.br/ojs/index.php/ies/article/view/9896

Araújo, E. (1999). Alvarenga de. Informação, sociedade e cidadania: gestão da informação no contexto de organizações nãogovernamentais (ONGs) brasileiras. Ci. Inf., 29(2), 155-167Retrieved October 15, 2015, from http://revista.ibict.br/index.php/ciinf/article/view/297

Associação Brasileira de Alergia e Imunologia - ASBAI (2009). Alergia alimentar. São Paulo: Retrieved May 6, 2015 from http://www.sbai.org.br/secao.asp?s=81\&id=306

Azevedo, M. A. de \& Marteleto, R. M. (2008). Informação e segurança pública: a construção do conhecimento social em ambiente comunitário. TransInformação, 20(3), 273-284, Retrieved October 16, 2015, from http://portaldeperiodicos.eci.ufmg.br/index.php/pci/article/download/267/59

Brasil. Law no 6.437, August 20, 1977. Configura infrações à legislação sanitária federal, estabelece as sanções respectivas, e dá outras providências. Diário Oficial [da República Federativa do Brasil], Brasília, DF, 20 ago. 1977. Retrieved October 19, 2016, from http://www.planalto.gov.br/ccivil 03/leis/L6437.htm

Binsfeld, B. de L. et al. (2009). Conhecimento da rotulagem de produtos industrializados por familiares de pacientes com alergia a leite de vaca. Rev. paul. pediatr., (27) 3, 296-302, Retrieved May 07, 2015, from

http://www.scielo.br/pdf/rpp/v27n3/10.pdf 
Cardoso, A. M. P. (1994). Retomando possibilidades conceituais: uma contribuição à sistematização do campo da informação social. Revista da Escola de Biblioteconomia da UFMG, 23(2), 107-114.

Frohmann, B. (2008). O caráter social, material e público da informação. In: Fujita, M.; Marteleto, R.; \& Lara, M. (Orgs). (2008). A dimensão epistemológica da ciência da informação e suas interfaces técnicas, políticas e institucionais nos processos de produção, acesso e disseminação da informação. São Paulo: Cultura Acadêmica; Marília: Fundepe. p. 19-34.

Gasque, K. C. G. D.; Costa, S. M. de S. (2010). Evolução teórico-metodológica dos estudos de comportamento informacional de usuários. Ci. Inf., 39(1), 21-32, Retrieved October 19, 2015, from http://revista.ibict.br/ciinf/index.php/ciinf/article/view/1206/1355

Hjørland, B. (2002). Domain analysis in information science. Journal of Documentation, 58 (4), 122-162.

Hjørland, B. \& Albrechtsen, H. (1995). Toward a new horizon in information science: domain-analysis. Journal of the American Society for Information Science, 46 (6), 400-425.

Jouis, C., et al. (2012). Next Generation Search Engines: Advanced models for information retrieval. IGI Publishing Hershey.

Lowy, M. (1985). Ideologia e Ciências Sociais: elementos para uma análise marxista. São Paulo: Cortez.

Marteleto, R. M. (1995). Cultura informacional: construindo o objeto informação pelo emprego dos conceitos de imaginário, instituição e campo social. Ci. Inf., 24(1). Retrieved October 15, 2015, from http://revista.ibict.br/index.php/ciinf/article/view/535

McKenzie, P. J. (2003). A model of information practices in accounts of everyday-life information seeking. Journal of Documentation, (59) 1, 19-40, 2003. Retrieved October 19, 2015, from http://www.emeraldinsight.com/doi/abs/10.1108/00220410310457993

Medeiros, M. M. de. (2005). Informação e representações sociais: estudo exploratório com familiares de portadores de sofrimento mental. (Master's thesis). Universidade Federal de Minas Gerais, Belo Horizonte, MG, Brasil.

Nascimento, D. M. \& Marteleto, R. M. (2004). A "Informação Construída" nos meandros dos conceitos da Teoria Social de Pierre Bordieu. DataGramaZero - Revista de Ciência da Informação, 5(5). Retrieved October 16, 2015, from http://www.datagramazero.org.br/out04/F___aut.htm

Pinto, F. V. M. \& Araújo, C. A. Á. (2012). Contribuição ao campo de usuários da Informação: Em Busca dos Paradoxos das Práticas Informacionais. Transinformação, 24(3), 219-226.

Rendón Rojas, M. Á. (2005). Relación entre los conceptos: información, conocimiento y valor. Semejanzas y diferencias. Ciência da Informação, 34(2), 52-61,

Rocha, J. A. P.; Sirihal Duarte, A. B.; Paula, C. P. A. de (2017). Modelos de práticas informacionais. Em Questão, v. 23, p. 3661.

Savolainen, Reijo. (2007). Information behavior and Information practice: Reviewing the "Umbrella Concepts" of InformationSeeking studies. The Library Quarterly, 77(2), 109-132. Retrieved October 27, 2015, from http://eric.ed.gov/?id=EJ875965

Yeoman, A. (2010). Applying McKenzie's model of information practices in everyday life information seeking in the context of the menopause transition. Information Research, (15) 4. Retrieved July 12, 2016, from http://InformationR.net/ir/154/paper444.html 


\section{Authors data}

Adriana Bogliolo Sirihal Duarte

Associate Professor of the Pós-graduação em Ciência da Informação at Universidade Federal de Minas Gerais (PPGCI/UFMG). Visiting professor at Florida State University's School of Information from August 2016 to July 2017.

bogliolo@eci.ufmg.br

\section{Flávia Moraes Moreira Barros}

Journalist at Universidade Federal de Minas Gerais (UFMG). Specialist in Strategic Information Management for the Núcleo de Informação Tecnológica e Gerencial (NITEG/UFMG). Master in Information Science from the Universidade Federal de Minas Gerais (PPGCI/UFMG).

flaviamoraesmoreira@gmail.com

Recibido - Received: 2017-05-27

Aceptado - Accepted: 2017-12-31

\section{(cc) EY}

This work is licensed under a Creative Commons Attribution 4.0

United States License.

\section{ULIS D-Sorke}

This journal is published by the University Library System of the University of Pittsburgh as part of its D-Scribe Digital Publishing Program and is cosponsored by the University of Pittsburgh Press. 